\title{
Ocena zmienności rytmu serca u pacjentów z nadciśnieniem tętniczym - przegląd systematyczny
}

\section{Assessment of heart rate variability in hypertensive patients - systematic review}

\author{
Małgorzata Maciorowska, Paweł Krzesiński
}

Klinika Chorób Wewnętrznych i Kardiologii Wojskowego Instytutu Medycznego w Warszawie

\section{Streszczenie}

Nadciśnienie tętnicze (AH) jest wiodącą przyczyną zgonu z przyczyn sercowo-naczyniowych oraz czynnikiem ryzyka wystąpienia choroby niedokrwiennej serca, niewydolności serca, niewydolności nerek oraz udaru mózgu. Dysfunkcja autonomicznego układu nerwowego (AUN) pozostaje istotnym elementem w rozwoju i progresji tego schorzenia, ale jej ocena nie jest powszechnie stosowana.

Analiza zmienności rytmu serca (HRV) jest metodą nieinwazyjnej oceny mechanizmów autonomicznych zaangażowanych w kontrolę układu krążenia. Analizy tej można dokonać, stosując różne metody, w tym analizę czasową, spektralną oraz techniki nieliniowe. Dane z dużych badań populacyjnych wskazują, że u osób z prawidłowym ciśnieniem tętniczym i obniżoną HRV istnieje zwiększone ryzyko rozwoju AH. Wykazano niższe wskaźniki HRV u osób z AH „białego fartucha”, a także u osób z nieprawidłowym profilem dobowym ciśnienia tętniczego. Podobnie obserwacje istnieją u pacjentów z powikłaniami narządowymi AH. Ujawniono także różnice w oddziaływaniu różnych grup leków hipotensyjnych na AUN, w tym szczególnie korzystny wpływ beta-adrenolityków oraz antagonistów receptora angiotensyny na HRV.

Celem niniejszej pracy jest przedstawienie analizy HRV jako dostępnej metody nieinwazyjnej oceny AUN oraz przesłanek potwierdzających jej przydatność w kompleksowej ocenie klinicznej pacjentów z AH, szczególnie w grupach chorych niskiego i umiarkowanego ryzyka i z subklinicznymi zaburzeniami funkcji układu krążenia.

Słowa kluczowe: zmienność rytmu serca, nadciśnienie tętnicze, dysfunkcja układu autonomicznego, ryzyko sercowo-naczyniowe

Folia Cardiologica 2018; 13, 5: 428-434

\section{Wstęp}

Nadciśnienie tętnicze (AH, arterial hypertension) jest główną przyczyną zgonu z przyczyn sercowo-naczyniowych oraz czynnikiem ryzyka wystąpienia: choroby niedokrwiennej serca, niewydolności serca, niewydolności nerek oraz udaru mózgu. Schorzenie to dotyczy $26 \%$ osób dorosłych na całym świecie [1]. Z powodu starzenia się populacji oraz narastającego problemu otyłości ocenia się, że do 2025 roku już jedna trzecia ludzi na całym świecie będzie dotknięta tym problemem. Według badania NATPOL 2011 rozpowszechnienie AH w populacji Polaków w wieku 18-79 lat wzrosło w ciągu 10 lat z 30\% do 32\%, czyli do około 9 mln osób, w badaniu WOBASZ II (Wieloośrodkowe Badanie Stanu Zdrowia Ludności), przeprowadzonym w 2014 roku, wynosiło już 43\%. Mimo że za rozwój AH odpowiada wiele czynników, wydaje się, że dysfunkcja układu autonomicznego jest istotnym elementem w rozwoju i progresji tego schorzenia. 
Nowe markery o znaczeniu rokowniczym są szczególnie przydatne w grupach chorych niskiego i umiarkowanego ryzyka, zwłaszcza z subklinicznymi zaburzeniami funkcji układu krążenia. Wydaje się, że stosunkowo łatwo dostępną metodą, przydatną jako element kompleksowej oceny klinicznej pacjentów, jest analiza zmienności rytmu serca (HRV, heart rate variability). Jest to metoda nieinwazyjnej, ilościowej oceny mechanizmów autonomicznych zaangażowanych w kontrolę układu krążenia. Przez ostatnich 30 lat w rosnącej liczbie badań wykazano związek dysfunkcji układu autonomicznego z rozwojem chorób układu sercowo-naczyniowego.

\section{Równowaga współczulno-przywspółczulna}

Nerwowa regulacja układu krążenia odbywa się przez współdziałanie dwóch ramion autonomicznego układu nerwowego (AUN): współczulnego i przywspółczulnego. W warunkach fizjologicznych aktywacji jednego z nich towarzyszy inhibicja drugiego, co umożliwia szybką odpowiedź sercowo-naczyniową na różne czynniki endo- i egzogenne, najczęściej pod postacią zmiany ciśnienia tętniczego bądź rytmu serca [2].

Analizy tej można dokonać, stosując różne metody, w tym analizę czasową, spektralną oraz techniki nieliniowe [3]. Ocena jest zazwyczaj oparta na długoterminowych (przynajmniej 18-godzinnych) zapisach elektrokardiologicznych (EKG) metodą Holtera. Analiza może być przeprowadzona również w krótkich 5-minutowych zapisach, ale w wystandaryzowanych warunkach, tak aby uniknąc wpływu bodźców zewnętrznych, które mogą oddziaływać na AUN. Wstępne opracowanie zapisu EKG obejmuje skorygowanie pobudzeń źle sklasyfikowanych, eliminację artefaktów, analizę arytmii i zmian odcinka ST. Analizie poddawane są tylko odstępy R-R między prawidłowymi zespołami QRS. Te, które wystąpiły przed pobudzeniem dodatkowym i po nim, nie są brane pod uwagę.

\section{Analiza czasowa HRV}

Podstawową analizowaną jednostką jest jeden pełny okres pracy serca między kolejnymi załamkami $\mathrm{R}$ rytmu zatokowego (NN, normal-to-normal interval), liczony w milisekundach. Parametry stosowane w analizie czasowej HRV moga być oparte bezpośrednio na zmienności odstępów R-R lub różnicy między kolejnymi odstępami R-R. Najprostszym i najpowszechniej używanym parametrem jest standardowe odchylenie od średniej ze wszystkich odstępów R-R (ms) (SDNN, standard deviation of normal to normal RR intervals) - odzwierciedla ono długoterminową HRV, przede wszystkim stopień funkcjonowania przywspółczulnego układu nerwowego. Ponieważ wskaźnik ten jest bezpośrednio związany z długością analizowanego zapisu, błędne jest porównywanie wartości SDNN uzyskanych z zapisów EKG o różnej długości. Wskaźniki (rMSSD, the square root of the mean of the sum of the squares of differences between adjacent NN intervals) i odsetek różnic między kolejnymi odstępami R-R przekraczający 50 ms (pNN50, percentage of NN50) (tab. 1) odzwierciedlają czynność części przywspółczulnej [3, 4]. Podobnie SDNN, odchylenie standardowe od średniej wartości R-R w kolejnych 5-minutowych przedziałach (SDANN, standard deviation of the averages of NN intervals in all 5 minutes segments of the entire recording), średnia z odchyleń standardowych od średniej wartości R-R w kolejnych 5-minutowych przedziałach (SDNNIX, standard deviations of all normal-to-normal RR intervals for all five-minute segments of the entire recording) opisują zmienność całkowitą.

\section{Analiza częstotliwościowa HRV}

Analiza częstotliwościowa (spektralna) HRV pozwala na zobrazowanie cyklicznych zmian zachodzących w układzie krążenia pod wpływem bodźców obwodowych i ośrodkowych i pośrednio odzwierciedla aktywność AUN i równowage

Tabela 1. Parametry stosowane w analizie czasowej zmienności rytmu serca (HRV, heart rate variability)

SDNN (standard deviation of normal to normal RR intervals) [ms]

SDSD (standard deviation of normal to normal RR intervals index)

SDANN (standard deviation of the averages of NN intervals in all 5 minutes segments of the entire recording) [ms]

SDNNI (mean of the standard deviations of all NN intrevals in all 5-min segments of the entire recordings) [ms]

rMSSD (the square root of the mean of the sum of the squares of differences between adjacent NN intervals) [ms] pNN50 (percentage of NN50)
Standardowe odchylenie od średniej ze wszystkich odstępów R-R; globalne odzwierciedlenie HRV

Odchylenie standardowe od średniej różnicy między kolejnymi odstępami R-R

Odchylenie standardowe od średniej wartości R-R w kolejnych 5-minutowych przedziałach

Średnia z odchyleń standardowych od średniej wartości R-R w kolejnych 5-minutowych przedziałach

Pierwiastek kwadratowy ze średniej sumy kwadratów różnic między kolejnymi odstępami R-R; odzwierciedla czynność części przywspółczulnej Odsetek różnic między kolejnymi odstępami R-R przekraczający $50 \mathrm{~ms}$ (\%); odzwierciedla czynność części przywspółczulnej 
między jej częścią przywspółczulną i współczulną. Wykonuje się ją za pomocą szybkiej transformaty Fouriera i pozwala z uzyskanego całkowitego widma częstotliwości wyróżnić komponenty składowe o niskiej częstotliwości (LF, low frequency; 0,04-0,15 Hz) i oscylacje o wysokiej częstotliwości (HF, high frequency; 0,15-0,4 Hz). W uproszczeniu można przyjąć, że oscylacje w zakresie wysokich częstotliwości (składowa HF) odpowiadają rytmowi oddychania i są uznawane za wskaźnik układu parasympatycznego. Na wartości LF wpływają zarówno nerw błędny, jak i układ sympatyczny. W warunkach spoczynku LF zależy od połączonego wpływu układu współczulnego i przywspółczulnego, po stymulacji współczulnej (np. pod wpływem pionizacji ciała, wysiłku fizycznego, napięcia psychoemocjonalnego) zaś staje się głównie wykładnikiem aktywności sympatycznej. Wzajemne relacje składowych LF i HF (wskaźnik LF/HF) odzwierciedlają równowagę współczulno-przywspółczulną.

\section{Analiza HRV u pacjentów z chorobami układu sercowo-naczyniowego}

Liczne publikacje wskazują, że przewlekły brak równowagi AUN, przejawiający się wzrostem aktywności współczulnego układu nerwowego i spadkiem aktywności przywspółczulnego, odgrywa istotną rolę w patofizjologii niewydolności serca [5], choroby wieńcowej oraz wiąże się z czynnikami ryzyka chorób układu sercowo-naczyniowego, takimi jak cukrzyca, nadciśnienie tętnicze, brak aktywności fizycznej [3, 6-8]. Udowodniono wartość prognostyczną obniżonej HRV u pacjentów po zawale serca [9]. Pojawiają się publikacje wskazujące na możliwość zastosowania analizy HRV w szacowaniu życiowego ryzyka wystąpienia chorób układu sercowo-naczyniowego [10].

\section{Ocena HRV u pacjentów z AH}

Od czasu pierwszego badania, w którym stwierdzono, że istnieje niewielka, ale znamienna pozytywna korelacja między wartością LF a ciężkością AH, wyrażaną wartościami rozkurczowego ciśnienia tętniczego $(r=0,30 ; p<0,01)$ [11], pojawiło się wiele publikacji, w których oceniano HRV u osób z AH.

Dysfunkcja AUN jest widoczna już na początkowych etapach $\mathrm{AH}[8,12,13]$. Chińscy badacze w pracy z 2006 roku wykazali obecność obniżonej modulacji przywspółczulnej jeszcze przed rozwojem AH oraz u osób z prawidłowym ciśnieniem tętniczym i dodatnim wywiadem rodzinnym w kierunku AH [14]. Porównano funkcję AUN w czterech grupach osób: z prawidłowym ciśnieniem tętniczym i dodatnim/negatywnym wywiadem rodzinnym w kierunku $\mathrm{AH}$, wysokim prawidłowym ciśnieniem tętniczym oraz z AH. Funkcję AUN oceniano w pozycji leżącej przez 5 minut po 15-minutowym odpoczynku, stosując: wskaźniki SDNN, LF, HF oraz współczynnik LF/HF, współczynnik między najdłuższym odstępem R-R w maksymalnym 30. pobudzeniu a najkrótszym R-R w maksymalnie 15. pobudzeniu po przyjęciu pozycji stojącej (30 max/15 min ratio) oraz współczynnik między najdłuższym odstępem R-R podczas wydechu a najkrótszym w czasie wdechu (E/I ratio). U osób z dodatnim wywiadem rodzinnym AH stwierdzono obniżenie współczynnika 30 maks./15 oraz HF w stosunku do osób z negatywnym wywiadem, co odzwierciedla obniżoną funkcję układu przywspółczulnego. W innych pracach wykazuje się wzrost LF u takich osób [15]. Różnice w otrzymanych wynikach mogą się wiązać z różnymi wartościami ciśnienia tętniczego przyjętymi jako prawidłowe.

Dane z dużych badań populacyjnych (podsumowane w tab. 2) wskazują, że osoby z prawidłowym ciśnieniem tętniczym i obniżoną HRV cechuje zwiększone ryzyko rozwoju AH [7, 15]. W prospektywnym badaniu Framingham [7] analizowano pierwsze 2 godziny zapisu EKG. Po uwzględnieniu innych czynników ryzyka wykazano związek obniżenia komponenty LF z rozwojem AH u mężczyzn w 4-letnim okresie obserwacji (iloraz szans [OR, odds ratio] 1,38; 95-proc. przedział ufności [Cl, confidence interval]), nie wykazano związku z SDNN i HF u żadnej z płci. Ponadto stwierdzono redukcję wskaźników HRV, z wyjątkiem współczynnika LF/HF u kobiet i mężczyzn z AH $(p<0,05)$. W badaniu ARIC (Atherosclerosis Risk in Communities) [17] potwierdzono zmniejszoną HRV u osób z AH (wskaźniki SDNN, rMSSD, R-R interval) w zapisach 2- i 6-minutowych. Wśród 7099 osób z wyjściowo prawidłowym ciśnieniem tętniczym obniżona HRV po uwzględnieniu współzmiennych wiązała się ze zwiększonym ryzykiem rozwoju $\mathrm{AH}$ w 9-letnim okresie obserwacji - współczynnik ryzyka (95\% Cl) SDNN 1,24 (1,10-1,40); RMSSD 1,36 (1,21-1,54); odstęp R-R 1,44 (1,27-1,63). W tym okresie nie stwierdzono różnicy między wartościami parametrów HRV po 9 latach obserwacji, co może sugerować, że AUN jest zaangażowany w rozwój $A H$, a różnice w funkcjonowaniu nie narastają w czasie. Liao i wsp. [16] badali związek między HRV ocenianą w 2-minutowym zapisie EKG w pozycji leżącej z AH w podgrupie 2061 osób wyróżnionych z badania ARIC. W 3-letnim okresie obserwacji 64 osoby rozwinęły $\mathrm{AH}$. Wykazano odwrotny związek wyjściowej wartości HF z rozwojem $\mathrm{AH}$. W przekrojowej analizie po uwzględnieniu wieku, rasy, płci, palenia tytoniu, cukrzycy i wykształcenia wskaźnik ten był znacząco niższy w grupie chorych z AH (leczonych i nieleczonych) niż u osób z normotensją. U osób z kwartylu z najniższą HRV ryzyko rozwoju AH było 2,44-krotnie wyższe. W badaniu obserwacyjnym Lucini i wsp. [18] z 2002 roku 300 osób z ciśnieniem tętniczym w zakresie od 90/60 mm Hg do 210/120 mm Hg, które były podzielone na trzy grupy ze średnim ciśnieniem tętniczym: 103, 133 i 163 mm Hg. Regulację AUN oceniano przy użyciu spektralnej analizy odstępów R-R i zmienności skurczowego ciśnienia tętniczego (brano pod uwagę zmiany w spoczynku i po przyjęciu pozycji stojącej), w celu uwzględnienia 
Tabela 2. Parametry zmienności rytmu serca (HRV, heart rate variability) jako predyktory rozwoju nadciśnienia tętniczego (AH, arterial hypertension)

\begin{tabular}{|c|c|c|c|c|c|}
\hline Autorzy & Badanie & Wiek & Populacja & $\begin{array}{l}\text { Czas } \\
\text { obserwacji }\end{array}$ & $\begin{array}{l}\text { Wskaźniki HRV korelujące z rozwojem nadciśnienia } \\
\text { tętniczego }\end{array}$ \\
\hline Liao i wsp. [16] & ARIC & 45-64 M, K & $\begin{array}{l}\text { Część przekro- } \\
\text { jowa } n=2061 \\
\text { część prospek- } \\
\text { tywna } n=1338\end{array}$ & 3 lata & $\begin{array}{l}\downarrow \text { HF, LF, SDNN u osób AH ( } p<0,001) \text {; w okresie } \\
\text { obserwacji odwrotna korelacja wyjściowej war- } \\
\text { tości HF z rozwojem AH (skorygowany OR [95\% } \\
\text { Cl]: } 1,00,1,46[0,61-3,46], 1,50 \text { [0,65-3,50] } \\
\text { i 2,44 [1,15-5,20] od najwyższego do najniższego } \\
\text { kwartylu) }\end{array}$ \\
\hline Singh i wsp. [8] & Framingham & $28-62 \mathrm{M}, \mathrm{K}$ & $\begin{array}{l}n=2042 ; \\
\text { (u 17\% osób } \\
\text { rozwinęło } \\
\text { się } A H)\end{array}$ & 4 lata & $\begin{array}{l}\downarrow \text { SDNN, LF, HF, VLF, TP, rMSSD, pNN50 w AH; } \downarrow \text { LF } \\
\text { u M (po skorygowaniu pod względem wieku płci, } \\
\text { BMI, spożycia alkoholu, palenia tytoniu oraz wyj- } \\
\text { ściowego SBP i DBP) predyktorem rozwoju AH }\end{array}$ \\
\hline $\begin{array}{l}\text { Schroeder } \\
\text { i wsp. [9] }\end{array}$ & ARIC & 40-54 M, K & $n=11061$ & 9 lat & $\begin{array}{l}\text { Skorygowany współczynnik hazardu }(95 \% \text { Cl): } \\
\text { SDNN } 124(1,10-1,24), \text { rMSSD 1,36 }(1,21-1,54) \text {, } \\
\text { odstęp R-R 1,44 (1,27-1,63) dla rozwoju AH }\end{array}$ \\
\hline
\end{tabular}

ARIC - Atherosclerosis Risk in Communities; M - mężczyzna; K - kobieta; $\mathrm{n}$ - liczba pacjentów; HF (high frequency) - składowa o wysokiej częstotliwości; LF (low frequency) - składowa o niskiej częstotliwości; SDNN (standard deviation of normal to normal RR intervals) - standardowe odchylenie od średniej ze wszystkich odstępów R-R; OR (odds ratio) - iloraz szans; Cl (confidence interval) - przedział ufności; VLF (very low frequency) - bardzo niska częstotliwość; TP (total power) - całkowita moc widma; rMSSD (the square root of the mean of the sum of the squares of differences between adjacent NN intervals) - pierwiastek kwadratowy ze średniej sumy kwadratów różnic między kolejnymi odstępami R-R; pNN50 (percentage of NN50) - odsetek różnic między kolejnymi odstępami R-R przekraczający 50 ms (\%); BMI (body mass index) - wskaźnik masy ciała; SBP (systolic blood pressure) - skurczowe ciśnienie tętnicze; DBP (diastolic blood pressure) - rozkurczowe ciśnienie tętnicze

komponenty współczulnej. Oznaki podwyższonej modulacji układu współczulnego (wzrost wartości LF, spadek wartości HF) były widoczne już u osób w 2. tercylu. Huikuri i wsp. [19] porównywali wskaźniki HRV u mężczyzn z prawidłowym ciśnieniem tętniczym oraz u osób leczonych z powodu AH dłużej niż 5 lat. Analizowali 45-minutowe zapisy EKG: 15 minut w pozycji leżącej, 15 minut w pozycji siedzącej, 15 minut w czasie chodzenia. U pacjentów z AH w porównaniu z grupą kontrolną stwierdzili: znamiennie niższe SDNN (52 \pm 19 v. $59 \pm 20$ mss; $p<0,01$ ), bardzo niską częstotliwość (VLF, very low frequency), LF, współczynnik LF/HF analizowane w znormalizowanych jednostkach zredukowane (dla ostatnich trzech parametrów $p<0,001$ ). Pacjenci z AH mieli również stłumione zmiany LF i HF w odpowiedzi na pionizację w porównaniu z grupą kontrolną. Po uwzględnieniu wyjściowych wartości ciśnienia tętniczego i wskaźnika masy ciała (BMI, body mass index) nie obserwowano znamiennych różnic w bezwzględnych wartościach wskaźników HRV, co sugeruje, że źle kontrolowane AH i otyłość są głównymi determinantami redukcji wskaźników HRV.

Również u osób z AH „białego fartucha” wykazano znacząco niższe HF $(p<0,03)$ i LF $(p<0,051)$ oraz większy współczynnik LF/HF niż u osób zdrowych $(p<0,03)$; nie stwierdzono różnicy między osobami z AH i AH „białego fartucha" [20].

\section{Czynność AUN zależnie od profilu dobowego HRV}

Di Raimondo i wsp. [21] wykonali analizę czasową HRV u pacjentów z różnym profilem dobowym ciśnienia tętniczego: u pacjentów z nadmiernym spadkiem ciśnienia tętniczego w godzinach nocnych (extreme dippers) oraz wyższymi wartościami ciśnienia tętniczego w godzinach nocnych (reverse dippers) w porównaniu z osobami z prawidłowymi wartościami ciśnienia tętniczego. Badacze wskazali na liniowy związek między redukcją wskaźnika noc/dzień i wzrostem aktywacji układu współczulnego (znacząca redukcja SDANN i SDNN w grupie reverse w trakcie dnia, w nocy oraz w ciągu 24 h). Nie wykazano natomiast różnicy w wartościach parametrów określających aktywność układu przywspółczulnego (pNN50, RMSSD) [21]. Wyniki te są spójne z wcześniejszymi wynikami z badań Kohara i wsp. [22], którzy, wykorzystując analizę spektralną, wykazali spadek LH i HF w grupie non-dippers w porównaniu z osobami z AH i prawidłowym spadkiem ciśnienia tętniczego.

\section{Zmienność rytmu serca u osób z powikłaniami narządowymi $\mathrm{AH}$}

W retrospektywnej analizie 200 pacjentów z AH przeprowadzonej we włoskim ośrodku [23] wykazano znacząco niższe wartości współczynnika LF/HF u pacjentów z umiarkowanym obniżeniem oszacowanego współczynnika filtracji kłębuszkowej (eGFR, estimated glomerular filtration rate) - z badania wyłączono pacjentów z GFR poniżej $30 \mathrm{ml} /$ $/ \mathrm{min} / 1,73 \mathrm{~m}^{2}(\mathrm{p}<0,001)$. Podobnie obniżone wartości wskaźników funkcji AUN, czyli SDNN i SDANN, stwierdzono u pacjentów z obecną blaszką miażdżycową w porównaniu z tymi z prawidłową grubością kompleksu błony środkowej i wewnętrznej tętnic szyjnych (IMT, intima media thickness). W niektórych pracach wykazano istotnie statystycznie niższą wartość komponenty LF $(p<0,05)$ u pacjentów 
z przerostem lewej komory w porównaniu z osobami z jej prawidłową geometrią [24]. Mandawat i wsp. [25] stwierdzili odwrotną relacje między parametrami HRV uzyskanymi z analizy czasowej (SDNN, triangular index i SDANN) a wskaźnikiem masy lewej komory (LVMI, left ventricular mass index) w grupie pacjentów z nadciśnieniem tętniczym (SDNN: $r=-0,233, p<0,05$; triangular index: $r=-0,288$, $p<0,01$; SDANN: $r=-0,245, p<0,05)$. Choć korelacja ta była lepsza u pacjentów z przerostem lewej komory wtórnym do patologii zastawki aortalnej (SDNN: $r=-0,597$, $p<0,001$; triangular index: $r=-0,521, p<0,001$; SDANN: $r=-0,459, p<0,001)$ [25].

Najwcześniejszą i najczęstszą konsekwencją AH jest dysfunkcja rozkurczowa. W wielu przypadkach zmiany funkcji rozkurczowej oceniane za pomocą echokardiografii są widoczne, zanim wystąpi przerost ścian lewej komory. Praca badaczy z włoskiego ośrodka [26] wykazała wyższy indeks LF mierzony po pionizacji u pacjentów z AH i dysfunkcją rozkurczową (definiowaną jako $\mathrm{E} / \mathrm{A}<1$ i czas decelaracji [DT, deceleration time] $>210 \mathrm{~ms}$ ) niż u osób z AH bez dysfunkcji rozkurczowej $(p<0,05)$; LF mierzony w spoczynku korelował istotnie statystycznie ze współczynnikiem E/A i po pochyleniu z DT fali E.

Tadic i wsp. [27] badali związek HRV z mechaniką lewej komory, ocenianą przy użyciu echokardiograficznej (dwuwymiarowej [2D, two-dimensional] i trójwymiarowej [3D, three-dimensional]) techniki śledzenia markerów akustycznych (STE, speckle tracking echocardiography) u pacjentów z nieleczonym AH [27]. Wykazali korelację z parametrami HRV: LVMI, E/E' oraz wartości odkształcania podłużnego i poprzecznego.

\section{Wpływ leczenia hipotensyjnego na HRV}

Korzyści z wpływu leczenia hipotensyjnego na układ sercowo-naczyniowy są dobrze udokumentowane. Badania wskazują na różnice w oddziaływaniu różnych grup leków hipotensyjnych na markery funkcji AUN. Należy jednak mieć na uwadze, że prowadzono je najczęściej w małych grupach, u osób z różnym stopniem zaawansowania $\mathrm{AH}$ i leczonych w niejednorodny sposób. Sprawia to, że trudno je porównywać.

Wykazano, że szczególnie beta-adrenolityki i antagoniści receptora angiotensyny (ARB, angiotensin-receptor blocker) pozytywnie wpływają na $\operatorname{HRV~[6,~28-30].~}$ Pierwsza grupa leków została bardzo dobrze przebadana, zwłaszcza w grupie pacjentów po zawale serca [28]. Menzes i wsp. [28] wykazali korekcję wszystkich wskaźników HRV (SDNN, pNN50, LF; p < 0,001) po 3-miesięcznej terapii inhibitorami konwertazy angiotensyny (ACE, angiotensin-converting enzyme) - enalaprilem lub ramiprilem - w porównaniu z grupą kontrolną. Petretta i wsp. [31] oceniali wpływ terapii lisinoprilem między innymi na parametry HRV. Po 12 miesiącach leczenia obserwowali obniżenie LVMI w całej grupie, w której $w$ analizie spektralnej podwyższeniu uległa jedynie składowa HF w nocy. Niemniej w grupie z normalizacją masy lewej komory stwierdzono podwyższenie wartości tej składowej w ciągu dnia i nocy oraz podwyższenie całkowitej mocy widma (TP, total power) i VLF w nocy w stosunku do wartości wyjściowych. Autorzy sugeruja, że normalizacja masy lewej komory i ciśnienia tętniczego wydają się niezbędne w celu uzyskania poprawy HRV. Istnieją również prace wskazujące, że terapia ARB oddziałuje korzystniej niż inhibitory ACE i beta-adrenolityki $[32,33]$. Podejmowano również próby oceny wpływu poszczególnych klas antagonistów wapnia na wskaźniki HRV [34-36]. Zwiększoną śmiertelność u pacjentów z AH i chorobą wieńcową, stosujących krótkodziałające pochodne dihydropirydynowe, tłumaczy się między innymi nadmierną aktywacją układu współczulnego w odpowiedzi na wazodylatację [37]. Długodziałające pochodne dihydropirydyny i niedihydropirydyny działają jako wazodylatatory, mają mniejszy wpływ na układ współczulny. Dane dotyczące wpływu amlodipiny na AUN są sprzeczne. Niektórzy badacze wykazują niewielki wpływ tego leku na AUN lub brak takiego wpływu, wzrost aktywności układu współczulnego bądź przeciwnie - stwierdzają stymulację nerwu błędnego [34-36].

\section{Podsumowanie}

Wydaje się, że analiza HRV, mimo pewnych ograniczeń, jest łatwo dostępną metodą nieinwazyjnej oceny układu autonomicznego, która może być przydatna w całościowej ocenie klinicznej pacjentów z AH, szczególnie w grupach chorych cechujących się niskim i umiarkowanym ryzykiem i z subklinicznymi zaburzeniami czynności układu sercowo-naczyniowego. Konieczne są dalsze badania służące ocenie wpływu poszczególnych grup leków hipotensyjnych na wskaźniki HRV, co może być przydatne w doborze farmakoterapii na poszczególnych etapach rozwoju AH.

\section{Konflikt interesów}

Autorzy nie zgłaszają konfliktu interesów. 


\section{Abstract}

Arterial hypertension $(\mathrm{AH})$ is the leading cause of cardiovascular mortality and a risk factor for ischaemic heart disease, heart failure, renal failure and stroke. Although many factors are responsible for AH development, autonomic dysfunction seems to be an important element in the development and progression of this disease.

Analysis of heart rate variability (HRV) offers a noninvasive, quantitative evaluation of the autonomic mechanisms involved in cardiovascular control. This analysis can be made using various methods, including time, spectral and nonlinear techniques. Data from large population studies indicate that people with normal blood pressure and reduced HRV have an increased risk of developing AH. Lower HRV rates have been demonstrated in people with 'white coat' hypertension, as well as in people with an abnormal daily blood pressure profile i.e. with an excessive blood pressure decrease at night (extreme dippers) or higher blood pressure values at night (reverse dippers) compared to people with normotension. Similar observations have been made in hypertensives with end-organ damage. Studies have shown the differing impacts of different groups of antihypertensive drugs on autonomic nervous system (AUN) function markers. A particularly beneficial effect on HRV of beta-blockers and angiotensin receptor antagonists has been demonstrated.

The analysis of heart rate variability, despite its limitations, is an easily available method of noninvasive assessment of the AUN. This may be useful as part of a comprehensive clinical assessment of hypertensive patients, especially in low-risk and medium-risk patients with subclinical cardiovascular disorders.

Key words: heart rate variability, hypertension, autonomic dysfunction, cardiovascular risk

Folia Cardiologica 2018; 13, 5: 428-434

\section{Piśmiennictwo}

1. Kearney PM, Whelton M, Reynolds K, et al. Global burden of hypertension: analysis of worldwide data. Lancet. 2005; 365(9455): $217-$ -223, doi: 10.1016/S0140-6736(05)17741-1, indexed in Pubmed: 15652604.

2. Somers VK. Sleep apnea and cardiovascular disease. In: Braunwald E, Bonow RO, Zipes DP, Libby P, Mann DL, Tomaselli GF. ed. Braunwald's heart disease: a textbook of cardiovascular medicine. Saunders, Philadephia 2012: 1931-1943.

3. Malik M, Bigger JT, Camm AJ, et al. Heart rate variability: Standards of measurement, physiological interpretation, and clinical use. Eur Heart J. 1996; 17(3): 354-381, doi: 10.1093/oxfordjournals.eurheartj.a014868.

4. Kleiger RE, Miller J, Bigger J, et al. Decreased heart rate variability and its association with increased mortality after acute myocardial infarction. Am J Cardiol. 1987; 59(4): 256-262, doi: 10.1016/00029149(87)90795-8.

5. Kleiger RE, Stein PK, Bigger JT. Heart rate variability: measurement and clinical utility. Ann Noninvasive Electrocardiol. 2005; 10(1): 88-101, doi: 10.1111/j.1542-474X.2005.10101.x, indexed in Pubmed: 15649244.

6. Guzzetti S, Piccaluga E, Casati R, et al. Sympathetic predominance in essential hypertension: a study employing spectral analysis of heart rate variability. J Hypertens. 1988; 6(9): 711-717, doi: 10.1097/00004872-198809000-00004, indexed in Pubmed: 3183374.

7. Gillman MW, Kannel WB, Belanger A, et al. Influence of heart rate on mortality among persons with hypertension: the Framingham Study. Am Heart J. 1993; 125(4): 1148-1154, doi: 10.1016/00028703(93)90128-v, indexed in Pubmed: 8465742.

8. Singh JP, Larson MG, Tsuji H, et al. Reduced heart rate variability and new-onset hypertension: insights into pathogenesis of hypertension: the Framingham Heart Study. Hypertension. 1998; 32(2): 293-297, indexed in Pubmed: 9719057.

9. Schroeder EB, Liao D, Chambless LE, et al. Hypertension, blood pressure, and heart rate variability: the Atherosclerosis Risk in Communities (ARIC) study. Hypertension. 2003; 42(6): 1106-1111, doi: 10.1161/01.HYP.0000100444.71069.73, indexed in Pubmed: 14581296.

10. Mark AL. The sympathetic nervous system in hypertension: a potential long-term regulator of arterial pressure. J Hypertens Suppl. 1996; 14(5): S159-S165, indexed in Pubmed: 9120673.

11. Bilchick KC, Fetics B, Djoukeng R, et al. Prognostic value of heart rate variability in chronic congestive heart failure (Veterans Affairs' Survival Trial of Antiarrhythmic Therapy in Congestive Heart Failure). Am J Cardiol. 2002; 90(1): 24-28, doi: 10.1016/s0002-9149(02)02380-9, indexed in Pubmed: 12088774.

12. Kubota Y, Chen LY, Whitsel EA, et al. Heart rate variability and lifetime risk of cardiovascular disease: the Atherosclerosis Risk in Communities Study. Ann Epidemiol. 2017; 27(10): 619-625.e2, doi: 10.1016/j. annepidem.2017.08.024, indexed in Pubmed: 29033120.

13. Julius $S$, Nesbitt $S$. Sympathetic overactivity in hypertension. A moving target. Am J Hypertens. 1996; 9(11): 113S-120S, doi: 10.1016/ /s0002-9149(02)02380-9, indexed in Pubmed: 8931844.

14. Schlaich MP, Lambert E, Kaye DM, et al. Sympathetic augmentation in hypertension: role of nerve firing, norepinephrine reuptake, and angiotensin neuromodulation. Hypertension. 2004; 43(2): 169-175, doi: 10.1161/01.HYP.0000103160.35395.9E, indexed in Pubmed: 14610101.

15. Wu JS, Lu FH, Yang YC, et al. Epidemiological study on the effect of pre-hypertension and family history of hypertension on cardiac autonomic function. J Am Coll Cardiol. 2008; 51(19): 1896-1901, doi: 10.1016/j.jacc.2007.12.053, indexed in Pubmed: 18466806. 
16. Liao D, Cai J, Barnes RW, et al. Association of cardiac autonomic function and the development of hypertension: the ARIC study. Am J Hypertens. 1996; 9(12 Pt 1): 1147-1156, doi: 10.1016/s0895-7061(96)00249-x, indexed in Pubmed: 8972884.

17. Piccirillo G, Viola E, Nocco M, et al. Autonomic modulation of heart rate and blood pressure in normotensive offspring of hypertensive subjects. J Lab Clin Med. 2000; 135(2): 145-152, doi: 10.1067/ /mlc.2000.103428, indexed in Pubmed: 10695659.

18. Lucini D, Mela GS, Malliani A, et al. Impairment in cardiac autonomic regulation preceding arterial hypertension in humans: insights from spectral analysis of beat-by-beat cardiovascular variability. Circulation. 2002; 106(21): 2673-2679, doi: 10.1161/01. cir.0000039106.89299.ab, indexed in Pubmed: 12438292.

19. Huikuri HV, Ylitalo A, Pikkujämsä SM, et al. Heart rate variability in systemic hypertension. Am J Cardiol. 1996; 77(12): 1073-1077, doi: 10.1016/s0002-9149(96)00135-x, indexed in Pubmed: 8644660.

20. Neumann SA, Jennings JR, Muldoon MF, et al. White-coat hypertension and autonomic nervous system dysregulation. Am J Hypertens. 2005; 18(5 (Pt 1)): 584-588, doi: 10.1016/j.amjhyper.2004.11.034, indexed in Pubmed: 15882538.

21. Di Raimondo D, Miceli G, Casuccio A, et al. Does sympathetic overactivation feature all hypertensives? Differences of sympathovagal balance according to night/day blood pressure ratio in patients with essential hypertension. Hypertens Res. 2016; 39(6): 440-448, doi: 10.1038/hr.2016.6, indexed in Pubmed: 26865002.

22. Kohara K, Nishida W, Maguchi M, et al. Autonomic nervous function in non-dipper essential hypertensive subjects. Evaluation by power spectral analysis of heart rate variability. Hypertension. 1995; 26(5): 808-814, doi: 10.1161/01.hyp.26.5.808, indexed in Pubmed: 7591022.

23. Melillo P, Izzo R, De Luca N, et al. Heart rate variability and target organ damage in hypertensive patients. BMC Cardiovasc Disord. 2012; 12: 105, doi: 10.1186/1471-2261-12-105, indexed in Pubmed: 23153340.

24. Galinier M, Pathak A, Fourcade J, et al. Left ventricular hypertrophy and sinus variability in arterial hypertension. Arch Mal Coeur Vaiss. 2001; 94(8): 790-794, indexed in Pubmed: 11575205.

25. Mandawat MK, Wallbridge DR, Pringle SD, et al. Heart rate variability in left ventricular hypertrophy. Br Heart J. 1995; 73(2): 139-144, indexed in Pubmed: 7696023.

26. Piccirillo G, Germanò G, Vitarelli A, et al. Autonomic cardiovascular control and diastolic dysfunction in hypertensive subjects. Int J Cardiol. 2006; 110(2): 160-166, doi: 10.1016/j.ijcard.2005.06.041, indexed in Pubmed: 16051387.

27. Tadic M, Cuspidi C, Pencic B, et al. Association between left ventricular mechanics and heart rate variability in untreated hypertensive patients. J Clin Hypertens (Greenwich). 2015; 17(2): 118-125, doi: 10.1111/jch.12459, indexed in Pubmed: 25496306.
28. Menzes AS, Moreira HG, Daher MT. Analysis of heart rate variability in hypertensive patients before and after treatment with angiotensin II-converting enzyme inhibitors. Arq Bras Cardiol. 2004; 83(2): 169-172, doi: 10/S0066-782X2004001400008, indexed in Pubmed: 15322659.

29. Lurje L, Wennerblom B, Tygesen $\mathrm{H}$, et al. Heart rate variability after acute myocardial infarction in patients treated with atenolol and metoprolol. Int J Cardiol. 1997; 60(2): 157-164, doi: 10.1016/s01675273(97)00104-6, indexed in Pubmed: 9226286.

30. Vesalainen RK, Kantola IM, Airaksinen KE, et al. Vagal cardiac activity in essential hypertension: the effects of metoprolol and ramipril. Am J Hypertens. 1998; 11(6 Pt 1): 649-658, doi: 10.1016/s08957061(98)00021-1, indexed in Pubmed: 9657623.

31. Petretta M, Bonaduce D, Marciano F, et al. Effect of one year of lisinopril treatment on cardiac autonomic control in hypertensive patients with left ventricular hypertrophy. Hypertension. 1996; 27(3, Pt 1): 330-338, doi: 10.1161/01.hyp.27.3.330, indexed in Pubmed: 8698434.

32. Lewandowski J, Abramczyk P, Dobosiewicz A, et al. The effect of enalapril and telmisartan on clinical and biochemical indices of sympathetic activity in hypertensive patients. Clin Exp Hypertens. 2008; 30(5): 423-432, doi: 10.1080/10641960802279132, indexed in Pubmed: 18633764.

33. Chern $\mathrm{CM}$, Hsu HY, Hu HH, et al. Effects of atenolol and losartan on baroreflex sensitivity and heart rate variability in uncomplicated essential hypertension. J Cardiovasc Pharmacol. 2006; 47(2): 169-174, doi: 10.1097/01.fjc.0000199225.17928.f5, indexed in Pubmed: 16495752.

34. Hamada T, Watanabe M, Kaneda T, et al. Evaluation of changes in sympathetic nerve activity and heart rate in essential hypertensive patients induced by amlodipine and nifedipine. J Hypertens. 1998; 16(1): 111-118, doi: 10.1097/00004872-199816010-00016, indexed in Pubmed: 9533424.

35. de Champlain J, Karas M, Nguyen P, et al. Different effects of nifedipine and amlodipine on circulating catecholamine levels in essential hypertensive patients. J Hypertens. 1998; 16(9): 1357-1369, doi: 10.1097/00004872-199816090-00017, indexed in Pubmed: 9746123.

36. Zaliūnas R, Brazdzionyte J, Zabiela V, et al. Effects of amlodipine and lacidipine on heart rate variability in hypertensive patients with stable angina pectoris and isolated left ventricular diastolic dysfunction. Int J Cardiol. 2005; 101(3): 347-353, doi: 10.1016/j.ijcard.2004.03.040, indexed in Pubmed: 15907400.

37. Psaty BM, Heckbert SR, Koepsell TD, et al. The risk of myocardial infarction associated with antihypertensive drug therapies. JAMA. 1995; 274(8): 620-625, doi: 10.1001/jama.1995.03530080036038, indexed in Pubmed: 7637142. 